\title{
APLIKASI FOAM-MAT FREEZE-DRYING UNTUK PRESERVASI KOMPONEN BIOAKTIF BUAH DAN INGREDIENT PANGAN FUNGSIONAL: REVIEW
}

\author{
Sandi Darniadi dan Sandro Pangidoan Siahaan \\ Balai Besar Litbang Pascapanen Pertanian \\ Jl. Tentara Pelajar No. 12, Cimanggu, Bogor, Indonesia \\ *Email korespondensi: sandidarniadi@pertanian.go.id
}

\begin{abstract}
ABSTRAK
Foam-mat freeze-drying merupakan metode pengeringan yang relatif baru dalam pengembangan produk pangan, khususnya produk olahan buah, dan preservasi komponen bioaktif pada buah. Metode ini merupakan kombinasi foam-mat drying (pengeringan busa) dan freeze drying (pengeringan beku). Aplikasi foam-mat freeze-drying memerlukan bahan hidrokoloid dan protein sebagai foam stabilizer dan foaming agent. Kondisi pengeringan dengan metode foam-mat freeze-drying yaitu suhu sangat rendah di bawah titik beku dan kondisi udara vakum, sehingga komponen bioaktif yang sangat sensitif terhadap temperatur tinggi dan oksidasi seperti: vitamin C, antosianin, senyawa fenolik, tidak mengalami penurunan yang cepat. Selain itu, metode foam-mat freeze drying mampu menghasilkan produk akhir yang memiliki karakteristik yang baik seperti warna, rasa, dan aroma seperti buah segar, tekstur renyah, struktur poros, kadar air dan aktivitas air rendah, serta dapat digunakan sebagai ingredient untuk pangan fungsional. Secara umum, foam-mat freeze-drying merupakan metode pengeringan yang tepat dalam mempertahankan komponen bioaktif pada buah, menghasilkan produk akhir dengan karakteristik fisiko-kimia dan sensori yang baik, dan produk akhir bermanfaat sebagai ingredient pangan fungsional yang diharapkan mampu meningkatkan kesehatan manusia.
\end{abstract}

Kata kunci: foam-mat freeze-drying, komponen bioaktif, buah, pangan fungsional

\begin{abstract}
Foam-mat freeze-drying (FMFD) is a relatively new drying method for food product development, particularly in fruit processing, and bioactive preservation of fruit products. This drying method is an incorporation between foam-mat drying and freeze-drying. The FMFD needs hydrocolloid as foam stabilizer and protein for foaming agent. Low temperature (less than the freezing point) and under vacuum condition during FMFD initiate the bio compounds, which are heat-sensitive and oxidationsensitive, such as vitamin C, anthocyanins, and phenolic compounds, are not drop drastically. Moreover, the FMFD is able to obtain best physico-chemical properties of the final products, such as color, flavor and aroma similar to the fresh one, porous structure, low moisture content and water activity, even the final products can be used for functional food ingredient. Overall, the FMFD is the best method for preserving bio active compounds of fruits, acquires good physical, chemical, and sensory properties, and obtain the final products which are for functional food and affect the human health.
\end{abstract}

Keywords: foam-mat freeze-drying, bio active compounds, fruits, functional foods 


\section{Pendahuluan}

Pengeringan dikategorikan sebagai metode tertua dalam pengawetan pangan dan selalu mejadi metode terbaik dalam pengawetan pangan dalam waktu panjang ${ }^{1}$. Secara tradisional, pengeringan merupakan salah satu proses untuk merubah produk pangan, baik dalam bentuk cair, padat, semi-cair, menjadi produk yang memiliki kadar air rendah yang stabil. Selama pengeringan, aktivitas air $\left(\mathrm{a}_{\mathrm{w}}\right)$ diturunkan serendah mungkin dan hal ini menjadikan produk pangan stabil terhadap mikroba pembusuk ${ }^{2}$. Perpindahan air pada produk pangan merupakan operasi perpindahan panas dan massa yang simultan 3. Panas menyebabkan penambahan energi yang cukup ke dalam air menyebabkan penguapan/evaporasi. Uap bergerak ke permukaan dari dalam produk pangan sebagai akibat perbedaan difusi uap air yang dihasilkan diantara lapisan-lapisan yang berbeda. Transfer panas dan massa terjadi pada level molekuler.

Meskipun produk pangan mengalami perubahan kualitas selama pengeringan sangat besar tetapi kemajuan terbaru pada teknik pengeringan telah membantu minimalisasi penurunan tersebut. Keterlibatan dan aplikasi teknik pengeringan baru telah mampu mengembangkan produkproduk kering baru dan produk pangan convenience yang memenuhi persyaratan kualitas dan stabilitas serta ekonomi ${ }^{1}$.

Powder buah-buahan merupakan salah satu bentuk pengolahan buah dan aplikasinya mendapat perhatian besar dari industri pangan. Powder buah-buahan umumnya digunakan sebagai powder rekonstitusi pada beberapa produk pangan lainnya yaitu susu, makanan bayi, kue, minuman, dan produk lainnya ${ }^{4}$. Keunggulan powder buah yang tidak seperti buah segar, yaitu umur simpan yang panjang, mudah dalam penyajian, volume dan berat lebih rendah, dan biaya transportasi lebih murah ${ }^{5}$.

Artikel ini bertujuan mereview salah satu teknologi pengeringan yang relatif baru yaitu foam-mat freeze-drying dalam pengolahan produk buah, khusunya powder buah. Pada artikel ini juga dibahas tentang mekanisme foam-mat freezedrying, pengaruh foam-mat freeze-drying pada produk akhir, dan penggunaan powder buah sebagai ingredient pangan fungsional.

\section{Studi terkini foam-mat freeze-drying pada buah}

Foam-mat freeze drying merupakan metode pengeringan yang relatif baru untuk menghasilkan buah kering dalam bentuk powder. Beberapa studi foam-mat freeze-drying yang telah dilakukan peneliti lain menunjukan keberhasilan dalam menghasilkan powder buah, seperti pada apel ${ }^{6}$, kurma ${ }^{7,8}$, dan blueberi ${ }^{9}$. Pada foam-mat freeze-drying kurma, proses foaming menggunakan maltodekstrin dan arabic gum pada konsenterasi 40 dan 50\%, buah kurma yang digunakan terdiri dari tiga tingkat kematangan yaitu khalal, rutab, dan tamr. Larutan foam dibekukan pada suhu $-80{ }^{\circ} \mathrm{C}$ selama 24 jam dan dilanjukan freeze-drying pada $-40{ }^{\circ} \mathrm{C}$ selama 72 jam. Hasil penelitian menunjukkan bahwa powder buah kurma yang dihasilkan menggunakan maltodekstrin memiliki karakteristik fisiko-kimia yang baik, tingkat wettability/kemudahan basah rendah dan kelarutan tinggi ${ }^{7}$. Hal ini mengindikasikan powder buah kurma yang memiliki kemampuan rekonstitusi yang baik. Karakteristik kimia dari powder kurma ini yaitu retensi total fenol powder kurma pada tingkat kematangan khalal mencapai $65-70 \%{ }^{7}$

Studi lain foam-mat freeze-drying yang dilakukan oleh Darniadi, et al. ${ }^{9}$ diaplikasikan pada buah blueberi. Proses foaming dilakukan dengan penambahan maltodekstrin (MD) dan whey protein isolate (WPI), dengan rasio MD:WPI 4 yaitu 4:10 dan 32:10 (b/b). Larutan foam dibekukan pada $-40{ }^{\circ} \mathrm{C}$ selama 24 jam dan dilanjutkan freeze-drying pada $-55{ }^{\circ} \mathrm{C}$ selama 24 jam. Hasil penelitian menunjukan bahwa foam-mat freeze-drying mampu mempertahankan total fenol berkisar 68$76 \%$, retensi total antosianin 95-98 \% dan retensi individual anosianin 81-98 \% 9 . Powder blueberi ini juga memiliki karaketristik fisik baik yaitu waktu larut singkat 70-75 detik, kelarutan 98\%, kadar air 3-4\% dan aktivitas air 0,3.

\section{Mekanisme foam-mat freeze-drying}

\section{Foam-mat freeze-drying}

Semua perbaikan teknologi terhadap metode freezedrying klasik untuk mengurangi biaya energi yang digunakan adalah ditujukan untuk beberapa hal yaitu: (a) untuk memperbaiki transfer panas pada tahap sublimasi, (b) untuk mengurangi waktu pengeringan, mengurangi kondisi vakum, (c) untuk mencegah pemakaian kondenser ${ }^{10}$. Beberapa peneliti teknologi pangan seperti Sharma dan Arora (1995) menyimpulkan bahwa pengurangan ketebalan sampel pangan dapat mengurangi waktu sublimasi dan waktu paparan temperatur tinggi pada lapisan sampel yang kering. Di sisi lain, beberapa peneliti telah berhasil menggunakan metode foaming/pembusaan untuk menurunkan waktu proses pengeringan udara panas konvesional pada sampel cair ${ }^{12,13}$.

Foam-mat drying telah dikenal lebih dari puluhan tahun untuk mengeringkan bahan pangan yang sensitif terhadap panas, termasuk produk buah. Pada foam-mat drying, bahan pangan yang akan dikeringkan diubah menjadi foam/busa sebelum mengalami proses pengeringan. Karim dan Wai (1999) mendefinisikan bahwa foam-mat drying merupakan proses untuk menghasilkan foam yang stabil menggunakan zat pembusa (berupa protein) dan zat penstabil foam (hidrokoloid) pada jus buah sebelum pengeringan (Gambar 1). Proses foammat drying memiliki tiga tahapan yaitu: persiapan bahan, whipping/pencampuran (foaming agent + foam stabilizer + bahan cair utama), dan pengeringan (suhu 60-70 ${ }^{\circ} \mathrm{C}$ ).

Foam yang stabil diperlukan pada tahap pertama foammat drying. Hal ini dapat dibuat melalui pengocokan campuran jus buah dan zat pembusa. Kemudian foam dituangkan pada wadah menjadi lapisan foam yang tipis dan dikeringkan dengan udara panas. Pada tahap akhir, lapisan foam kering kemudian dihaluskan menjadi powder halus. Dibandingkan teknologi 
pengeringan lainnya seperti spray-drying, foam-mat drying mampu mengurangi waktu pengeringan dan menggunakan suhu pengeringan yang rendah. Foam yang terbentuk dapat membantu meningkatkan luas permukaaan bahan yang terkena panas dimana hal ini mengakselerasi pengurangan air dari dalam bahan ${ }^{14}$. Foam ini juga memberikan keuntungan yaitu meningkatkan total luas area permukaan untuk pengeringan, sehingga memperbaiki laju waktu pengeringan ${ }^{16}$.

Metode foam-mat freeze-drying adalah penggabungan foam-mat drying dan freeze-drying untuk membuat produk pangan kering dari bentuk cair ${ }^{15}$. Foam-mat freeze-drying bertujuan untuk mengeringkan pangan dari bentuk cair, menurunkan waktu selama kondisi vakum pada freeze-drying dan mempertahankan nutrisi dan fitokimia pada produk akhir ${ }^{6}$. Foam-mat freeze-drying terdiri dari empat tahap utama: (a) penambahan zat pembusa dan zat penstabil foam ke dalam jus buah, dan mengocok campuran untuk membentuk foam stabil menggunakan mixer dapur atau blender. Proses pengocokan dilakukan pada temperatur kamar dengan kecepatan 3000-4000 rpm selama 3-7 menit, (b) membekukan lapisan foam tipis, (c) proses freeze-drying foam untuk menghasilkan lapisan foam kering menggunakan freeze-dryer (Gambar 2), dan (d) menghancurkan dan menghaluskan lapisan foam kering untuk menghasilkan free flowing powder. Diagram alir proses foammat freeze-drying ditunjukan pada Gambar 3.

\section{Protein sebagai zat pembusa}

Protein memiliki sifat sebagai zat aktif permukaan dan sebagai zat pembusa. Beberapa jenis protein yang berasal dari tumbuhan dan hewan digunakan dalam proses pengeringan (foam-mat drying, spray drying, foam-mat freeze-drying), yaitu putih telur, whey protein isolate (WPI), hydrolysed whey protein (HWP), calcium caseinat (CCP), soy protein isolate $(\mathrm{SPI})$, pea protein isolate $(\mathrm{PPI})$, rice protein isolate (RPI) ${ }^{16}$.

Mekanisme terbentuknya foam/busa yaitu dilakukan secara mekanis melalui whipping/pengocokan foaming agent dalam bahan cair utama (Gambar 4). Metode lain dalam pembentukan busa yaitu melalui sparging/penyemburan yang menghasilkan ukuran gelembung yang seragam, tetapi busa yang dihasilkan melalui pengocokan lebih seragam ${ }^{1}$. Protein sebagai foaming agent yang bagus membantu dalam pembentukan film yang kuat, viskoelastis, dan kohesif, yang memiliki kestabilan thermal dan mekanis. Busa yang terbentuk akan stabil selama proses foam-mat freeze-drying, tidak mengalami collapse ${ }^{1}$.
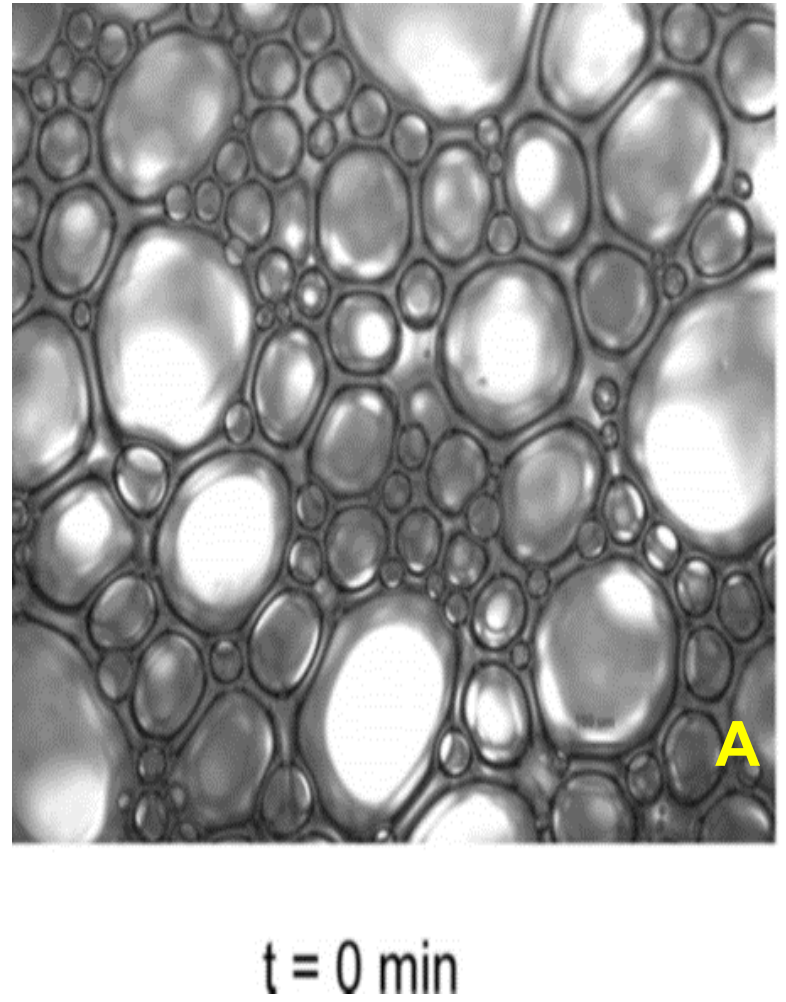

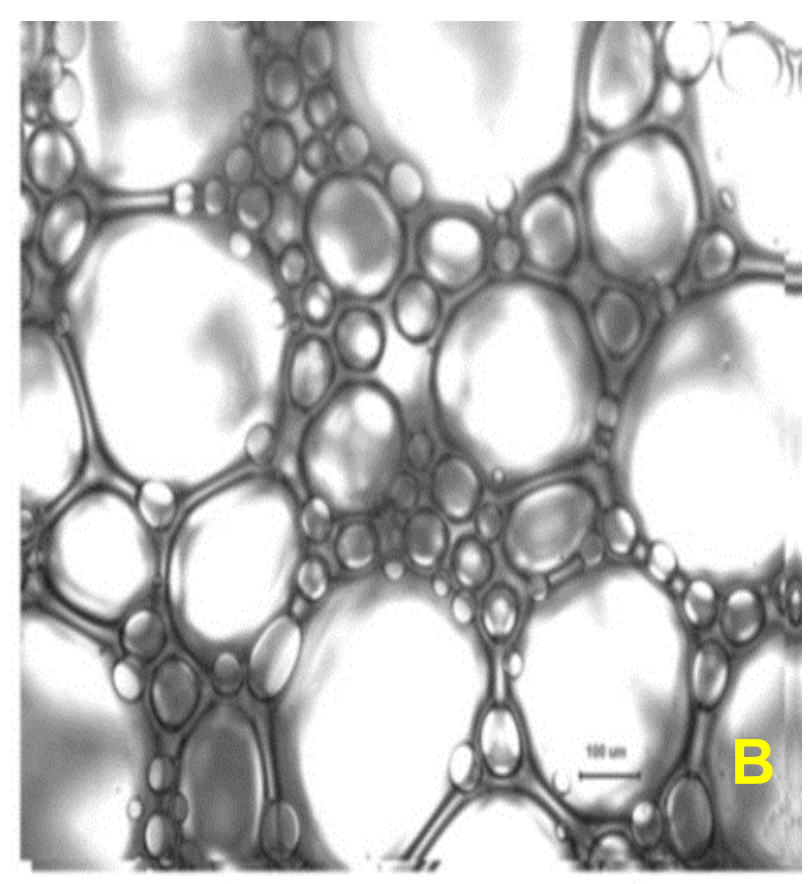

$t=20 \mathrm{~min}$ 
Gambar 1. Foam jus apel dengan $0,5 \%$ b/b powder putih telur setelah pengocokan (A) dan setelah 20 menit disimpan (B). Diadaptasi dari Ratti and Kudra (2006)

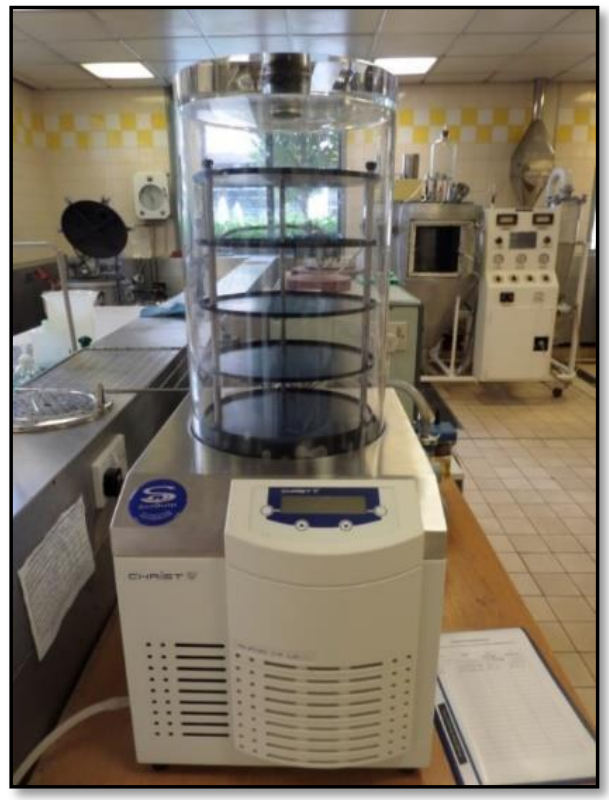

Gambar 2. Freeze-dryer skala laboratorium

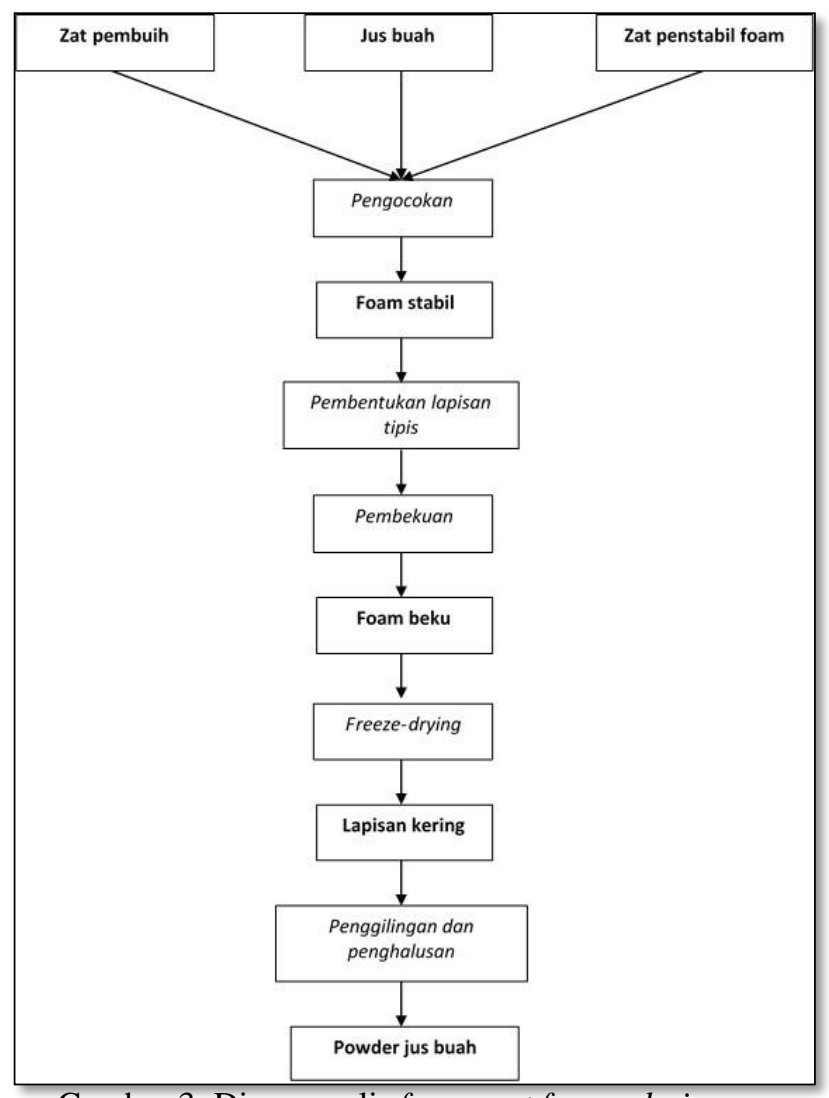

Gambar 3. Diagram alir foam-mat freeze-drying
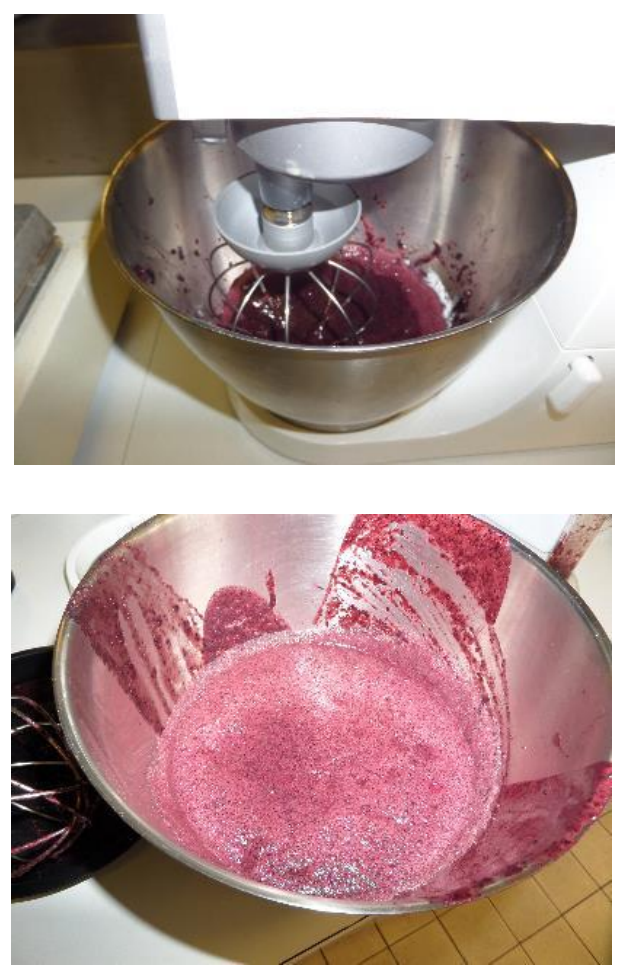

Gambar 4. Proses whipping protein dalam jus buah dan foam yang terbentuk

\section{Karbohidrat sebagai zat penstabil busa}

Penggunaan karbohidrat, khususnya hidrokoloid, pada proses foam-mat freeze-drying adalah sebagai zat pestabil busa. Hidrokoloid lebih dibanyak digunakan untuk menstabilkan busa karena kemampuannya untuk meningkatkan viskositas larutan yang mampu mengurangi kecepatan drainase/pengurangan air dan permeabilitas gas dari lamella (Gambar 5) ${ }^{17}$. Hidrokoloid yang biasanya digunakan pada proses foam-mat freeze-drying adalah maltodekstrin, trehalose, xanthan gum, arabic gum, dan cyclodextrin. Maltodekstrin mempunyai kemampuan untuk membentuk gel dan menahan air, oleh karena itu digunakan di industri pangan sebagai texture modifier. Fungsi lain dari maltodekstrin yaitu pembetukan film, pelindung bahan pangan dari oksigen, membantu kelarutan, dan mengikat flavor ${ }^{18}$. 


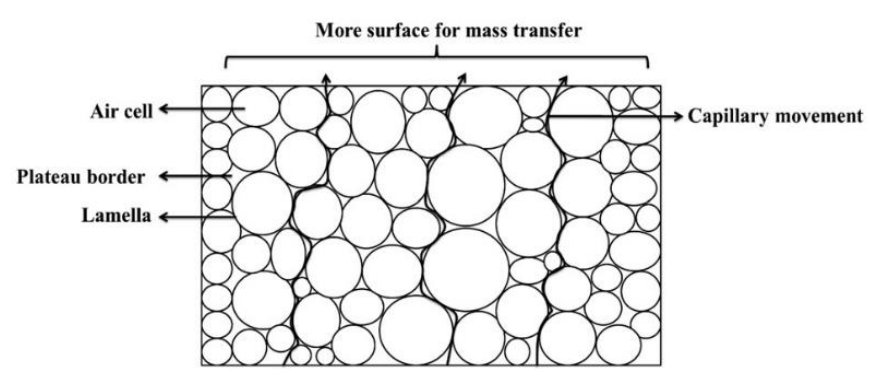

\section{Gambar 5. Struktur foam}

\section{Aplikasi Foam-mat freeze-drying pada buah}

\section{Preservasi komponen bioaktif buah}

Pengaruh proses pengolahan pada buah umumnya menyebabkan penurunan nutrisi dan komponen bioaktif. Buahbuahan memiliki komponen bioaktif yang penting bagi manusia, yaitu antosianin, ellagitanin, flavonol, flavanol ${ }^{19}$. Buah-buahan dari golongan beri-berian seperti stroberi, blueberi, blackberry, raspberi/arbei dan blackcurrant banyak mengandung antosianin. Senyawa antosianin merupakan senyawa yang bertanggung jawab atas pigmen (warna) buah. Terdapat lebih dari 25 jenis senyawa antosianin pada buahbuahan golongan beri. Senyawa antosianin bermanfaat sebagai antioksidan bagi tubuh manusia.

Antosianin sangat sensitif terhadap oksigen, suhu, cahaya dan kelembaban. Beberapa penelitian pengolahan pengeringan buah menunjukan penurunan antosianin akibat proses panas pada suhu lebih dari $60^{\circ} \mathrm{C}$. Proses pengeringan udara panas seperti pengering lorong, pengering kabinet, dan spray-dryer untuk pengolahan buah biasanya mengakibatkan kehilangan yang tinggi pada komponen bioaktifnya. Oleh karena itu, metode pengeringan yang menggunakan suhu rendah dapat mencegah penurunan antosianin yang cepat. Foam-mat freeze-drying mampu menghasilkan produk kering yang memiliki sifat fisiko-kimia yang baik (warna, rasa, dan aroma seperti buah segar, tekstur renyah, struktur poros, kadar air dan aktivitas air rendah), dan melindungi komponen bioaktif 15 .

Tabel 1 Total fenol dan antosianin pada powder kurma dan blueberi

\begin{tabular}{|l|c|c|}
\hline \multicolumn{1}{|c|}{ Karakteristik kimia } & Powder kurma ${ }^{\text {a) }}$ & Powder blueberi $^{\text {b) }}$ \\
\hline Total fenol(mg/g powder) & $0,95-1,6$ & $25-30$ \\
\hline Retensi total fenol (\%) & $65-70 \%$ & $68-76$ \\
\hline Total antosianin (mg/g cyn-3-gl powder) & $\left.{ }^{*}\right)$ & $5,7-6$ \\
\hline Retensi total antosianin (\%) & $\left.{ }^{*}\right)$ & $95-98$ \\
\hline Retensi individual antosianin (\%) & $\left.{ }^{*}\right)$ & $81-98$ \\
\hline
\end{tabular}

Darniadi et al., (2019) menggunakan metode foam-mat freezedrying untuk pengolahan buah blueberi. Zat pembusa dan zat penstabil busa yang digunakan dalam studi ini yaitu maltodekstrin (MD) dan whey protein isolate (WPI) pada berbagai konsenterasi. Kondisi proses foam-mat freeze-drying yang digunakan adalah suhu kondensor $-55{ }^{\circ} \mathrm{C}$ dan tekanan vakum 0,04 mbar selama 24 jam. Hasil penelitian ini menyimpulkan bahwa powder blueberi berwarna ungu gelap (seperti warna blueberi segar) yang diduga berhubungan dengan konsenterasi antosianin yang masih tinggi. Konsenterasi total fenol (TPC) dan total monomeric antosianin (TMA) powder blueberi berkisar 29,4-32,8 mg/g GAE blueberi (berat kering) dan 7,1-8,1 mg/g Cyanidin-3-glycoside (berat kering), secara berurutan. Retensi TPC dan TMA pada powder blueberi yang dihasilkan menggunakan metode foam-mat freeze-drying yaitu $68-73 \%$ dan $80-90 \%$, secara berurutan.

Di sisi lain, metode spray-drying juga digunakan untuk menghasilkan powder blueberi dan hasilnya menunjukan penurunan signifikan pada TMC dan TMA, dimana konsenterasi kedua komponen tersebut berkisar 20,8-23,3 mg/g GAE blueberi (berat kering) dan 4,3-5,3 mg/g Cyanidin-3- glycoside (berat kering), secara berurutan. Nilai retensi kedua komponen TPC dan TMA berkisar 48-69 \% dan 49-60\%, secara berurutan ${ }^{9}$.

\section{Ingredient pangan fungsional}

Foam-mat freeze-drying dinilai menjadi metode yang efektif untuk proses pengolahan pengeringan buah, terutama buah-buah yang mengandung komponen bioaktif yang penting bagi kesehatan, contohnya: antosianin pada buah-buahan berwarna merah dan ungu. Penggunaan antosianin pada sistem pangan lebih sesuai untuk makanan asam ( $\mathrm{pH}$ rendah) untuk memastikan keunggulan kation flavylium ${ }^{20}$. Sebagai contoh, antosianin biru, baik sebagai makanan utuh ataupun bentuk isolasi umumnya stabil pada $\mathrm{pH} 1$, dan antosianin turunannya juga memiliki kestabilan yang sama pada $\mathrm{pH} 2$, tetapi sangat berbeda pada $\mathrm{pH}$ 5. Hal ini dapat dijelaskan dengan penggunaan utama antosianin ekstrak seperti pigmen anggur dalam minuman dan minuman ringan sekitar $3 \mathrm{~kg}$ dari $1 \%$ ekstrak antosianin ditambahkan pada 1000 liter minuman dapat memberi warna merah gelap ${ }^{20}$. Tabel 1 menunjukan total fenol 
dan antosianin buah kurma dan blueberi yang diproses melalui foam-mat freeze-drying.

Manfaat antosianin, yang diperoleh dari proses pengolahan buah, yaitu memiliki efek kesehatan pada manusia. Beberapa manfaat tersebut diataranya: (a) antioksidan yaitu membantu pertahanan tubuh terhadap oksigen reaktif dan radikal bebas dan membantu menurunkan risiko penyakit kronis seperti penyakit jantung, dan kanker, (b) efek kesehatan mata melalui modulasi hal merugikan dari A2E pada pigmen retina, sehingga mampu memperbaiki night-vision seseorang, (c) anti-obesitas dan anti-diabetes melalui polifenol yang terkandung banyak pada buah berwarna biru atau merah, (d) anti-karsinogenik yang mampu mencegah penyakit kanker melalui sifat anti-proliferatif, pro-oksidan dan efek apoptotic dan juga kemampuannya untuk mengatur ekspresi gen ${ }^{20}$.

Secara keseluruhan, proses foam-mat freeze-drying merupakan salah satu metode alternatif terhadap freeze-drying konvensional, karena menghasilkan karakteristik fisik yang lebih baik dengan kemampuan proteksi yang bagus terhadap komponen bioaktif pada buah dan menghasilkan produk akhir yang dapat digunakan sebagai ingredient pangan fungsional.

\section{Daftar Pustaka}

1. Qadri OS, Srivastava AK, Yousuf B. Trends in foam mat drying of foods: Special emphasis on hybrid foam mat drying technology. Crit Rev Food Sci Nutr [Internet]. 2019;0(0):1-10. Available from: https://doi.org/10.1080/10408398.2019.1588221

2. Silva CLM, Oliveira SM, Branda TRS. Influence of Drying Processes and Pretreatments on Nutritional and Bioactive Characteristics of Dried Vegetables : A Review. 2015;

3. Jafari SM, Ghanbari V, Ganje M, Dehnad D. Modeling the drying kinetics of green bell pepper in a heat pump assisted fluidized bed dryer. J Food Qual. 2016;39(2010):98-108.

4. Fracassetti D, Del Bo' C, Simonetti P, Gardana C, KlimisZacas D, Ciappellano S. Effect of Time and storage temperature on anthocyanin decay and antioxidant activity in wild blueberry ( Vaccinium angustifolium ) powder. J Agric Food Chem [Internet]. 2013 Mar 27;61(12):29993005.

5. Bhandari B. Introduction to food powders. In: Bhandari B, Bansal N, Zhiang M, Schuck P, editors. Handbook of Food Powder. Cambridge: Woodhead Publishing Ltd.; 2013. p. $1-26$.

6. Raharitsifa N, Ratti C. Foam-Mat Freeze-Drying of Apple Juice Part 2: Stability of Dry Products During Storage. J Food Process Eng [Internet]. 2010 Feb [cited 2014 May 22];33(2010):341-64. Available from: http://doi.wiley.com/10.1111/j.1745-4530.2009.00517.x

7. Seerangurayar T, Manickavasagan A, Al-Ismaili AM, AlMulla YA. Effect of carrier agents on physicochemical properties of foam-mat freeze-dried date powder. Dry Technol [Internet]. 2017;0(0):1-12. Available from: https://www.tandfonline.com/doi/full/10.1080/07373937.2

\subsection{7}

8. Seerangurayar T, Manickavasagan A, Al-Ismaili AM, AlMulla YA. Effect of carrier agents on flowability and microstructural properties of foam-mat freeze dried date powder. J Food Eng [Internet]. 2017;215:33-43. Available from: http://dx.doi.org/10.1016/j.jfoodeng.2017.07.016

9. Darniadi S, Ifie I, Ho P, Murray BS. Evaluation of total monomeric anthocyanin, total phenolic content and individual anthocyanins of foam-mat freeze-dried and spray-dried blueberry powder. Food Meas Charact. 2019;13(1):1599-606.

10. Ratti C. Freeze drying for food powder production. In: Bhandari B, Bansal N, Zhang M, Schuck P, editors. Handbook of Food Powder. 1st ed. Cambridge: Woodhead Publishing; 2013. p. 57-84.

11. Sharma NK, Arora CP. Influence of product thickness, chamber pressure and heating conditions on production rate of freeze-dried yoghurt. Int J Refrig. 1995;18(5):297-307.

12. Karim AA, Wai CC. Foam-mat drying of starfruit (Averrhoa carambola L.) puree. Stability and air drying characteristics. Food Chem. 1999;64(3):337-43.

13. Ratti C, Kudra T. Drying of Foamed Biological Materials: Opportunities and Challenges. Dry Technol. 2006;24(9):1101-8.

14. Raharitsifa N, Genovese DB, Ratti C. Characterization of apple juice foams for foam-mat drying prepared with egg white protein and methylcellulose. J Food Eng Phys Prop [Internet]. 2006;71(3):E142-51. Available from: http://www.scopus.com/inward/record.url?eid=2-s2.033646365671\&partnerID=40\&md5=afb8ba6769ea72d512 4bed5d141afe 5d

15. Darniadi S, Ifie I, Luna P, Ho P, Murray BS. Foam-Mat Freeze-Drying of Blueberry Juice by Using Trehalose- $\beta$ Lactoglobulin and Trehalose-Bovine Serum Albumin as Matrices. Food Bioprocess Technol. 2020;

16. Fang Z, Wang R, Bhandari B. Effects of Type and Concentration of Proteins on the Recovery of Spray-Dried Sucrose Powder. Dry Technol [Internet]. 2013 Oct 26 [cited 2014 May 22];31(13-14):1643-52. Available from: http://www.tandfonline.com/doi/abs/10.1080/07373937.20 13.770011

17. Klitzing R V., Müller HJ. Film stability control. Curr Opin Colloid Interface Sci. 2002;7(1-2):42-9.

18. Reuther F, Plietz P, Damaschun G, Purschel H-V, Krober R, Schierbaum F. Structure of maltodextrin gels-a small angle X-ray scattering study. Colloid Polym Sci [Internet]. 1983 Mar;261(3):271-6. Available from: http://link.springer.com/10.1007/BF01469675

19. Giampieri F, Tulipani S, Alvarez-Suarez JM, Quiles JL, Mezzetti B, Battino M. The potential impact of strawberry on human health The strawberry : Composition, nutritional quality , and impact on human health. Nutrition. 2012;28:919.

20. Shipp J, El-Sayed, Abdel-Aal M. Food Applications and Physiological Effects of Anthocyanins as Functional Food Ingredients. Open Food Sci J. 2010;4:7-22. 